\title{
INVESTIGATIONS REGARDING BEAR CAVE MASSIF (LOWER SILESIA) LONG-TERM STABILITY
}

\author{
RAZISKAVE DOLGO ČASOVNE STABILNOSTI KRAŠKEGA \\ MASIVA: MERITVE NA OBMOČJU MEDVEDJE JAME V SPODNJI \\ ŠLEZIJI NA POLJSKEM
}

\author{
Krzysztof MĄKOLSKI ${ }^{1^{*}}$, Stefan CACOŃ ${ }^{1}$, Olgierd JAMROZ ${ }^{1^{*}}$, Blahoslav KOŠŤÁK ${ }^{2^{*}}$ \& Mirosław KACZAŁEK ${ }^{1^{*}}$
}

\begin{abstract}
UDC 551.234.1(437.3)

Krzysztof Mąkolski, Stefan Cacoń, Olgierd Jamroz, Blahoslav Košták \& Mirosław Kaczałek: Investigations regarding Bear Cave massif (Lower Silesia) long-term stability

Bear Cave under Mt Śnieżnik is located near the Lower Silesian Village of Kletno in a wider tectonic fault zone of Sudeten, Klodzko Valley, South Poland. Stability requirements along the visitor's path in the cave called for permanent checks of possible rock movements in the massif, while mining operations in the neighbouring marble quarry represented major threat to cave stability. Precise levelling network for vertical movements in the cave and its vicinity was established about 20 years ago. Outside the cave in the Kleśnica River valley levelling traverses were crossing tectonic faults. Periodical measurements have been repeated since 1984. In the cave two fault zones of major risk have been checked also with TM-71 crack gauges and records have been taken with a month frequency. These two were the tectonic crack zones of the Water Corridor and the main fault structure of the cave found in the Cascade Alley. Fourteen years ago after finding that quarry blasts induced increased movements in the cave, quarry operations were stopped. Recently, gradual subsidence of some levelling bench-marks was observed, as well as some periods of increased micro-displacements on the tectonic crack zones. Such observations are discussed.
\end{abstract}

Keywords: active faults monitoring, Bear Cave, crack gauge, precise levelling, deformation analysis.
Izvleček

UDK 551.234.1(437.3)

Krzysztof Mąkolski, Stefan Cacoń, Olgierd Jamroz, Blahoslav Košták \& Mirosław Kaczałek: Raziskave dolgo časovne stabilnosti kraškega masiva: meritve na območju Medvedje jame v Spodnji Šleziji na Poljskem

$\mathrm{V}$ članku obravnavamo raziskave premikov $\mathrm{v}$ masivu na območju Medvedje jame (Bear cave) pod Snežnikom (Śnieżnik) v bližini vasi Kletno v Spodnji Šleziji. Masiv spada v širše sudetsko tektonsko območje doline Klodzko, Južna Poljska. Zaradi zahtev po stabilnosti hribine ob turističnih poti v jami, smo vzpostavili stalno spremljavo premikov kamninskih mas v masivu. Stabilnost so ogrožala izkopavanja v bližnjem kamnolomu marmorja. Mreža nivojskih točke za beleženje vertikalnih premikov je bila vzpostavljena že pred dvajsetimi leti. V dolini reke Kleśnice smo v zadnjih letih redno spremljali več profilov $\mathrm{z}$ nivojskimi točkami. $\mathrm{V}$ jami smo $\mathrm{v}$ izbrane razpoke dveh prelomnih con namestili merilce premikov TM-71 v njih mesečno beležili premike. Pred štirinajstimi leti, ko so odkrili, da miniranje $\mathrm{v}$ kamnolomu povzroča večje premike $\mathrm{v}$ jami, so izkopavanja ustavili. V zadnjem času smo opazili pogrezanje nekaterih območij nivojskih točk in zaznali več obdobij povečanih premikov $\mathrm{v}$ spremljanih razpokah. $\mathrm{V}$ članku obravnavamo opisana opazovanja.

Ključne besede: opazovanje aktivnih prelomih, Medvedja jama, natančno niveliranje, analiza deformacij.

${ }^{1}$ Institute of Geodesy and Geoinformatics, Wroclaw University of Environmental and Life Sciences, Grunwaldzka 53, 50-357 Wroclaw, Poland

${ }^{2}$ Institute of Rock Structures and Mechanics, Czech Academy of Sciences, V Holešovičkách 41, 841 09, Prague 8, Czech Republic *Corresponding author’s e-mail: makolski@kgf.ar.wroc.pl, olgierd.jamroz@up.wroc.pl

Received/Prejeto: 23.01.2008 


\section{INTRODUCTION}

Natural processes like slope deformations and even Earth crust movements, as well as deformations caused by ever increasing human activities (mine and quarry exploitation, great hydrotechnical works, etc.) call for investigation. It becomes essential especially in areas where hazardous situations can develop regarding nearby engineering objects and endangered ecosystems. Superficial displacement checks made by geodetic means are most common. Their results may show not only expected changes due to superficial processes, like weathering and rock washing, as well as slope movements but the results may display even more intricate processes connected with long-term deep seated stress transformation in massifs and cumulative stresses in the rocks and in epicenters of earthquakes. High precision techniques are needed to identify such effects. Precise levelling, the well known procedure of geodesy, is one of the oldest deformation measurement methods used over 100 years. It enables monitoring of the crustal vertical movements with great precision.

Deformations observed on the crust surface are interfered with atmospheric and climatic conditions. Because of that, characteristic amplitudes and variations in frequency can be observed. Therefore, precise analysis of deformations due to such intricate deep seated rock effects and their identification in the results is rather difficult and need an additional and special analysis (Czaja \& Latoś 1996; Milev \& Papo, 1998).

Formation of limestone in the Klodzko Valley, Southern Poland, where Bear Cave is located, is dated back to the time of 570 millions years ago - turn of Wend and Cambrian (Don \& Opletal 1996; Ciężkowski 2006). In those days most of the Central Europe was covered by sea. Sedimentation of the lime deposits could possibly be running for 515 million years. It was interrupted by the old Caledonian folding. As a result, marbles were formed due to metamorphic processes (Don \& Opletal, 1996). During the Caledonian orogenesis volcanic events appeared under water and plenty of magma intrusions penetrated the upper folded formations. It was recognized that karst voids at middle cave level originat- ed at the beginning of Pliocene (5-4 million years ago). The Bear Cave discovery was made in 1966 as a result of the Kletno III mines exploitation. Till today about $3300 \mathrm{~m}$ of corridors have been investigated on three levels there. Corridors in a total length of $360 \mathrm{~m}$ have been opened as tourist tracks since 1983. The cave is protected as Bear Cave Reserve with an area of about 89 hectares. The length of underground rivers is about $5 \mathrm{~km}$ and they carry about $30 \mathrm{~m}^{3}$ of rock material per year out of the inner space of the cave.

Opening the Bear Cave in Kletno for public called for permanent stability observations in the area. It was recognized that karst voids inside and in the vicinity of the rock massif reduce the stability, and marble exploitation in the neighbouring quarry represent a major threat. Therefore, precise levelling network to monitor vertical movements in the cave and the vicinity was established about 20 years ago. Additionally, two crack gauges TM-71 were installed in the cave. One of them was installed in the tectonic crack zone into which the Water Corridor was driven. This installation was done in 1985. Second gauge was set on the principal structure of the cave found in the Cascade Alley in 1993 and data have been registered in a month interval. Crack gauges enable to determine 3D movements between opposite rock block faces. Thus, relative displacements on tectonic fault structures can be investigated. Combined results of the long-term cave research on the basis of precise levelling and of the crack gauging made possible to estimate the dynamics of movements in the rock massif of the cave. They proved instability of the rock massif due to blasting in the nearby quarry in early days of public cave exploration. That brought about a decision that the Kletno I quarry should be closed, which took place in March 1993. After that the instability symptoms caused by quarry operations ceased.

Further analysis of precise levelling bench-mark displacements before and after the quarry operations is presented and can be useful in similar surveys methodically.

\section{SETTING OF THE PRECISE LEVELLING NETWORK}

Geodetic measurements concerning rock massif deformations inside and in the vicinity of the cave started in 1984.

Localization of the network points had to take into consideration geological, tectonic, and geomorphologic characteristics of the massif. Only then the network could be arranged and measurements started. Therefore, following steps had to be done.

The first steps concern geology for proper positioning of the levelling network points (Cacon et al. 1989 - Fig. 1) with studies into: 
- The position of verified tectonic faults (SW - NS) between the cave and Kletno I quarry,

- An assumed position of tectonic faults along the Kleśnica River,

- The thickness and range of quaternary formation,

- The range of older geological formations (including crystalline),

- Details and topography.

The second step is the geodetic work:

- Precise levelling - Network in the cave surroundings, along the Kleśnica River and Kletno - Kamienica road, 23 points (Fig. 1);

- Precise levelling - Network inside the cave along the tourist path consisting of 24 points (Fig. 2). 16 points are being measured at present.
Network points located outside the cave were stabilized by concrete blocks down to depths below ground freezing level. Points inside the cave were fixed with metal pins preserved by rust-proof coat.

Analysis of results proved some instability of benchmarks located in the vicinity of the entrance pavilion. Such a conclusion was confirmed by visible small fissures on the walls, as well as cracks in the pavilion floor. To determine subsidence of the pavilion 13 points were set out in September 1987 (8 inside and 5 outside the pavilion). After some restructuring, this network consists of 5 bench-marks inside and 6 outside the pavilion. In the period 1984-2007 four damaged bench-marks had to be restored. These were points 3, 4, 7 and 27 .

\section{METHODICAL PRINCIPLES AND INSTRUMENTATION}

Every year measurements are performed repeatedly during the summer period of June and July by members of Students' Scientific Circle of Geodesists. The Circle, which now celebrates 45 years of existence, is presently joined with the Institute of Geodesy and Geoinformatics in Wroclaw.

Measurements are made using compensative levels of high precision: $\mathrm{Ni} 002$, Ni 004, Ni 007, precise levelling rods with brackets and metal wedges needed for detailed identification of implicit measurement points. Precise invar levelling rods are periodically checked with a comparative levelling rod, which allows corrections of altitudes between controlled bench-marks. Exterior measurements proceed in two opposite directions with a control of circuit closures. In case those such closures exceed permitted limits, measurements of sections showing the biggest differences are repeated. Corrected results of measurements from each cycle are elaborated using Cgeo v.7 software by Softline.

After the stability of reference points have been analysed, the elevation of controlled bench-marks is appointed with reference to two reference points $(10,21$ - see Fig. 1) recognized as fixed, and located not far from the cave entrance. Twenty two observation campaigns were completed during the period in question.

\section{ANALYSIS AND GEOMETRICAL INTERPRETATION OF RESULTS}

Calculations made after each part of measurements provide:

a/ adjusted bench-mark elevations $\left(\mathrm{H}_{\mathrm{i}}\right)$ and their mean errors $\left(\mathrm{m}_{\mathrm{Hi}}\right)$;

b/ displacements of controlled bench-marks $\left(\Delta \mathrm{H}_{\mathrm{i}}\right)$ and their mean errors $\left(\mathrm{m} \Delta_{\mathrm{Hi}}\right)$.

Displacements of the controlled bench-marks received since 1994 and their errors are presented in Table 1. Results from earlier periods are available (Cacon et al. (1996).

\section{DISPLACEMENTS OF BENCH-MARKS $\triangle \mathrm{H}$ AND THEIR MEAN ERRORS OUTSIDE AND INSIDE THE BEAR CAVE}

Displacements of controlled bench-marks in altitude are recognized significant (Table 1 -marked in bold) according to the following formula:

$$
\mathrm{P}\left[\Delta \mathrm{H}_{\mathrm{i}} \geq \mathrm{t}_{\alpha, \mathrm{h}} \times \mathrm{m} \Delta_{\mathrm{Hi}}\right]=\alpha
$$

where: $t_{a, h}$ - limit value of $t$ - Student's distribution with $\alpha$ and $h$ degrees of freedom (Hellwig 1978). 


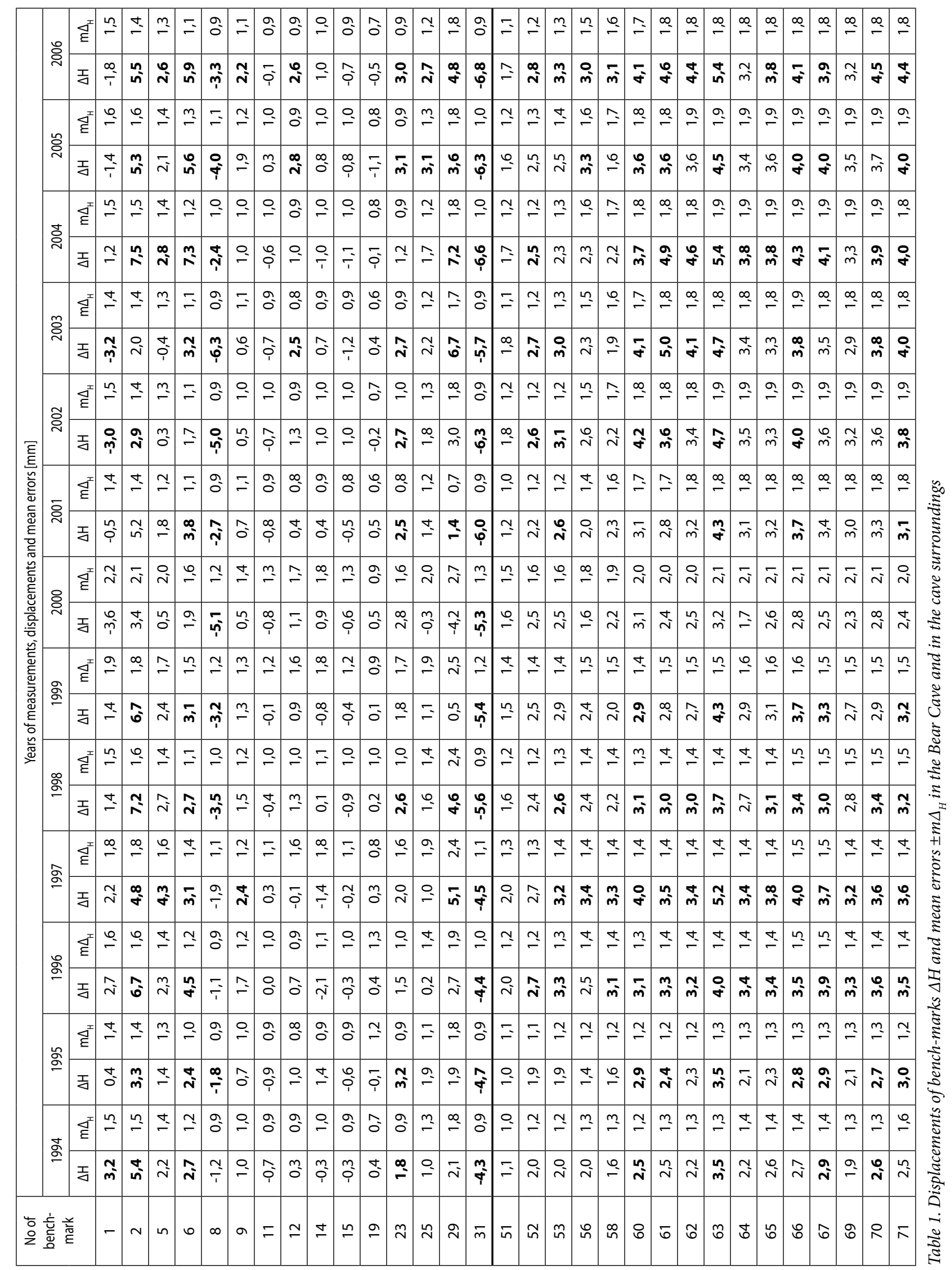


Displacements with values over $\mathrm{t}_{\mathrm{\alpha}, \mathrm{h}}=2$ were accepted as significant with $\mathrm{P}=95 \%$. Displacements of benchmarks with lower values are also presented in the table since the aim was to observe the altitude drift of particular bench-marks during the analysed periods.

From control bench-mark changes one can infer following facts:

- Displacements with values over $3.0 \mathrm{~mm}$ and 4.0 $\mathrm{mm}$ (mean errors $\pm 1.5 \mathrm{~mm}$ outside, i.e. on the massif surface, and $\pm 2.0 \mathrm{~mm}$ inside the cave) have been recognized as significant;

- Significant drift of most bench-marks has been observed inside the cave since 1991, indicating uplift;

- Fluctuations are found on bench-marks in the surroundings of the cave. The changes depend on the position of individual bench-marks in respect to the quarry

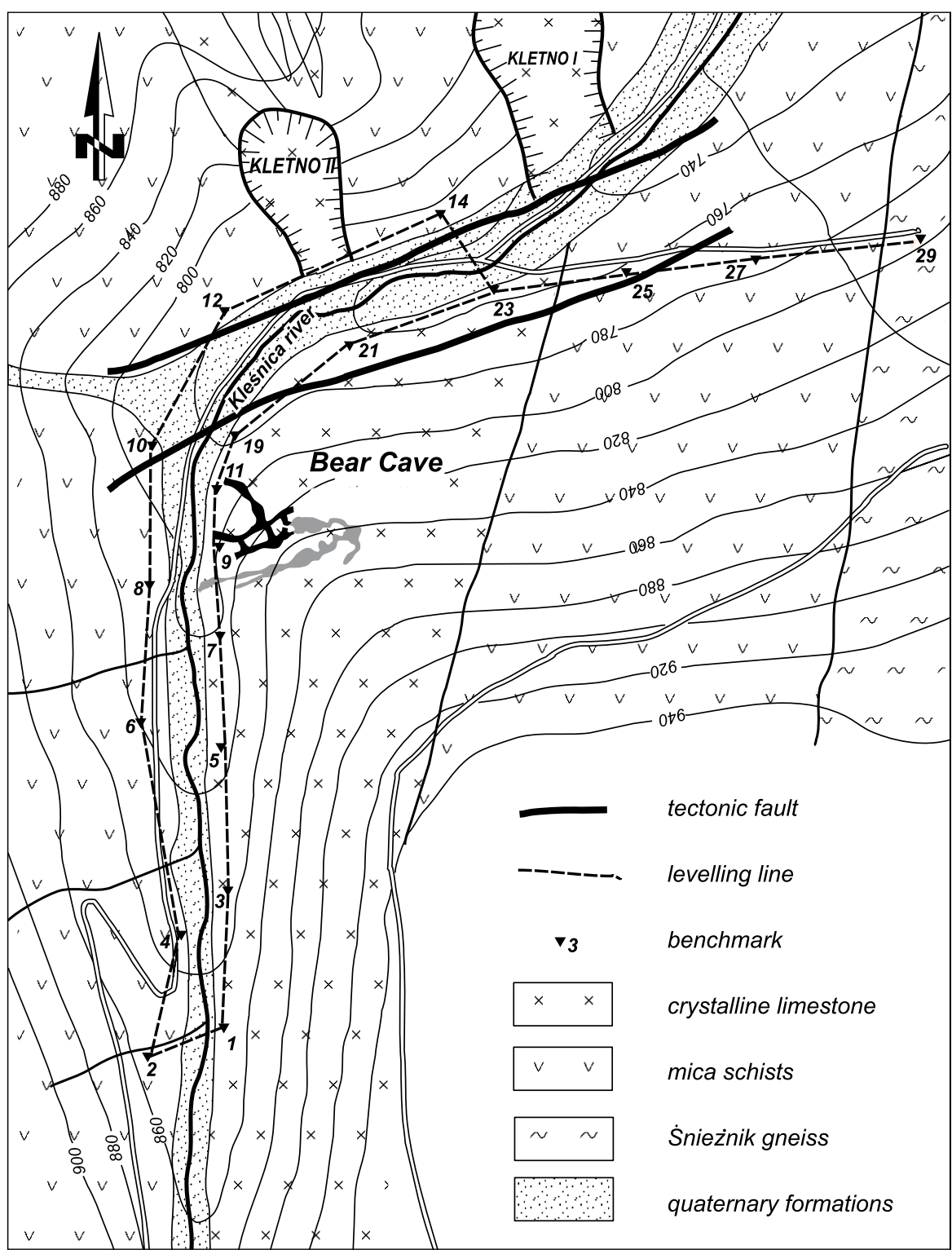

(active until 1993) and to tectonic faults. Such changes may indicate gradual redistribution caused probably by a delay in which blast wave effects from the quarry reached effectively the marks (Cacon et al. 1996);

- There appears an interpretation problem. Uplift of the control bench-marks located inside the cave can suggest also subsidence of the fixed reference points (10, 21), since bench-marks 9 and 11 located outside but belonging to the same massif formation did not indicate any significant uplift.

\section{INTERPRETATION OF THE RESULTS OF BENCH- MARKS DISPLACEMENT DIFFERENCES}

Graphs of resulting displacements are arranged in pairs. The reason is to see possible effect of geological and tectonic structure of the massif and particularly of the faults located on the surface (Fig. 1) and inside the cave (Fig. 2). Moreover, faults not identified before could be traced.

There is a necessity to recognize two different periods in the observations that respect exploitation work in the nearby quarry Kletno I where blasting operations were frequent. The quarry was closed in 1993. Therefore, the first period covers years 1984-1993, the second 1993-2006. Consequently, any interpretation must take this important change of activities in the cave surroundings into account. The two periods in the graphs of Fig. 3 are separated by a vertical line.

Quantitative data for the interpretation of displacements are presented by individual graphs in Fig. 3, and the discussion of observations regarding individual pairs of bench-marks follows. Points 10 and 21 were accepted as the reference points.

Fig. 1: Precise levelling network in Bear Cave surroundings. 


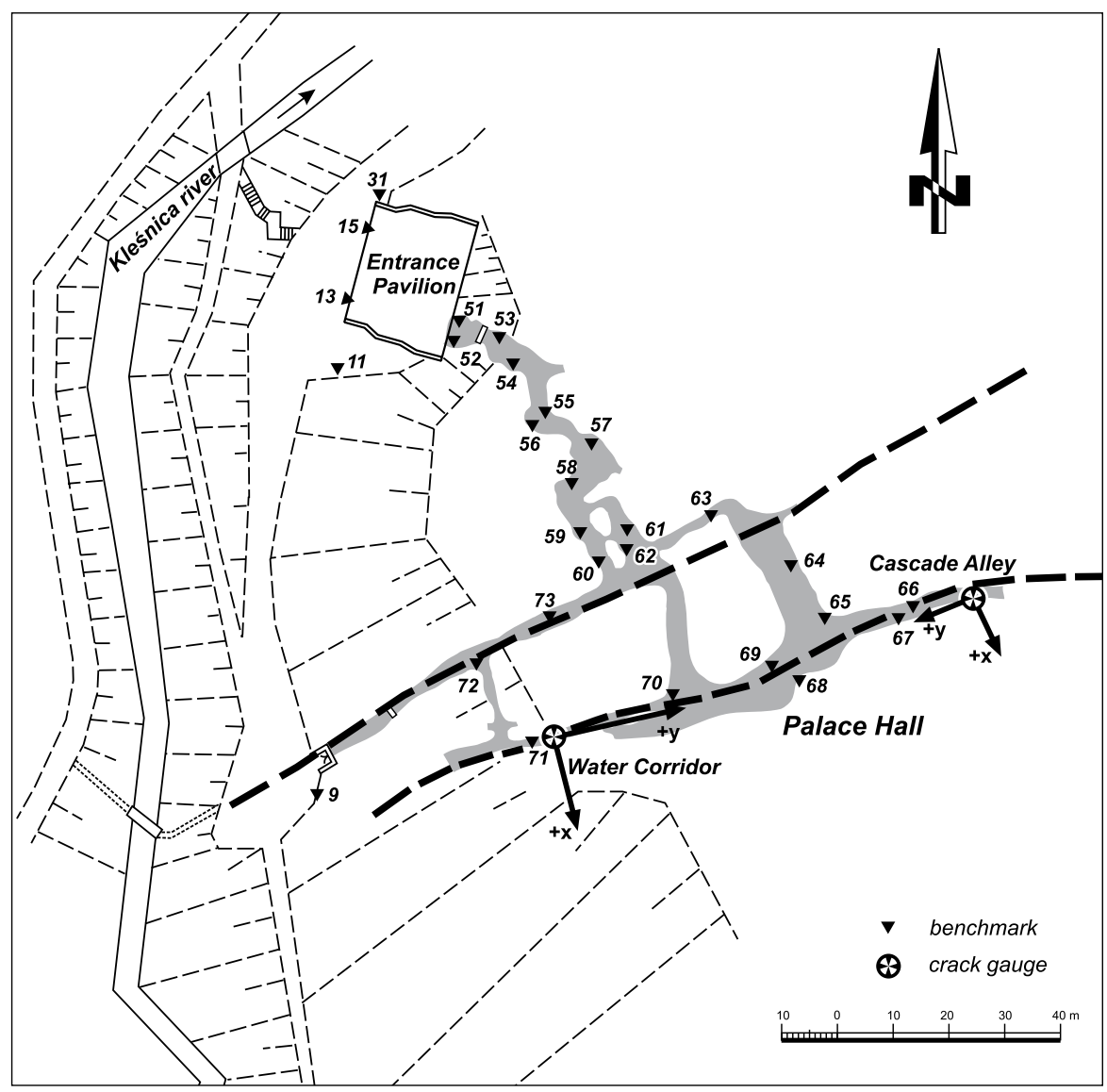

Fig. 2: Positioning of bench-marks and crack gauges TM-71 in Bear Cave.
Bench-marks on SE slope of the Kleśnica River bank - marble outcrops.

9 - 11: The course $9-11$ is almost parallel, lines separated by about $2 \mathrm{~mm}$. Individual changes do not exceed $1 \mathrm{~mm}$. Localization of the benchmarks on the same geological structure of marbles not fractured confirmed.

5 -9: The course of relative changes in 5 shows variations in the range of -0.5 to $+5 \mathrm{~mm}$ not parallel with 9. Bench-marks located on the same geological structure on the outcrop of marbles but a discontinuity indicated.

1 - 5: The course of both the points shows similarity with variations in the range of -4 to $+6 \mathrm{~mm}$. Bench-marks located on the same geological structure on the outcrop of marbles but a discontinuity indicated.
Bench-marks on opposite sides of the faults indicated by geology.

14 - 23: The two points, 14 and 23, are positioned on opposite sides of one fault of the two running along the northern bent section of the Kleśnica River, not far from the originally active quarry Kletno I. The graph course of the two is almost parallel. However, the graph lines are separated by about $2 \mathrm{~mm}$. The difference originated early, and appeared first at point 23. A minor but significant reduction of displacements after finishing the quarry exploitation can be observed.

10 - 12: Fluctuations in 12 reach up to $3 \mathrm{~mm}$ confirming activity of the "north" fault. Reduction of displacements after finishing the quarry exploitation can be observed.

10 - 11: The course 11 stabilized not exceeding $1 \mathrm{~mm}$ variations. Activity of the „south” fault not confirmed.

19 - 21: The course 19 stabilized not exceeding $1 \mathrm{~mm}$ variations. Activity of the „south” fault not confirmed.
Bench-marks on NW slope of the Kleśnica River bankmica schists - Stronie series.

2 - 6: The course of both the points shows similarity with uplifts up to $8 \mathrm{~mm}$. Bench-marks located on the same geological structure of mica schist - Stronie series, and uplift is indicated.

Bench-marks on opposite sides of the Kleśnica River banks.

5 - 6: The course is principally similar until the year 2000 when point 6 shows uplift of up to $7 \mathrm{~mm}$, i.e. relative uplift of mica-schist side at this section of mica schist - marble contact.

1 - 2: The course is principally similar until the year 1997 when the two lines separated by $3 \mathrm{~mm}$, and yet later to $4 \mathrm{~mm}$, and point 1 reached subsidence by $4 \mathrm{~mm}$, i.e. relative uplift of mica-schist side (see 5 - 6) together with even more accelerated subsidence of marble side at this section of mica schist - marble contact. 


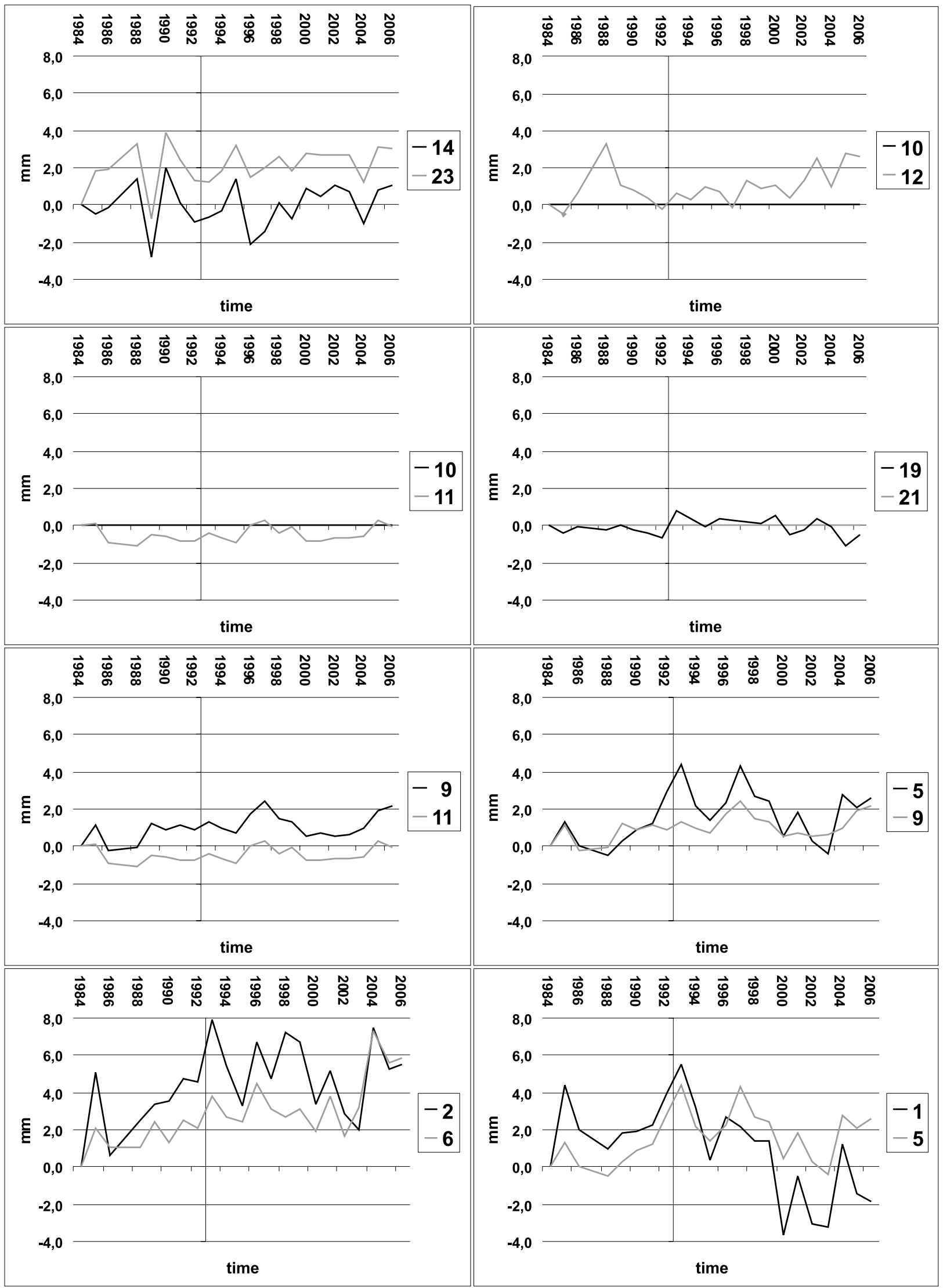




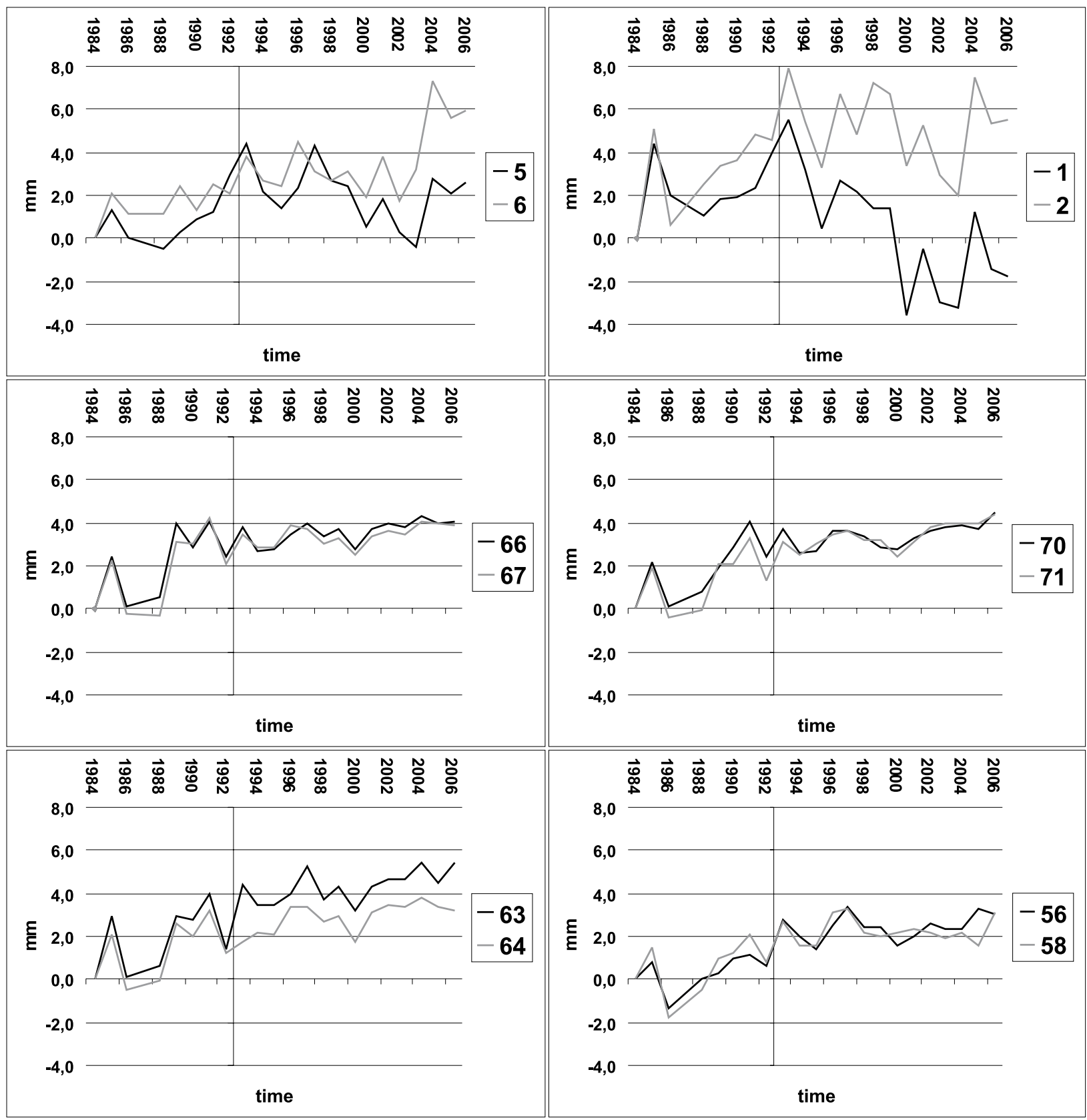

Fig. 3: Bench-mark displacements inside the Bear Cave and in the cave surroundings.

(Vertical line on the time axis marks the end of quarry Kletno I operations in March 1993).

Bench-marks inside of the Bear Cave.

66-67: Opposite sides of a tectonic line near Cascade Alley, close to a crack gauge.

Clear parallel course of the two points. The difference reaches only up to $0.3 \mathrm{~mm}$ in a long period 1997-2004 with the only exception of 1988-1989 when the difference reached about $1 \mathrm{~mm}$. Significant decrease of variations after 1993 when the quarry was closed.
70 - 71: In the Water Corridor, near the crack gauge set on Cascade Alley tectonic line.

Clear parallel course of the two points. The highest differences by about $1 \mathrm{~mm}$ measured in two periods: 1986-1990 and 1999-2002. Significant decrease of variations after 1993 when the quarry was closed.

63 - 64: In the Stalactite Alley, opposite sides of a fault zone oriented parallel to the Palace Hall fault. 
Clear parallel course of the two points until 1992. In 1993, during the last intensive quarry exploitation, a difference of $2 \mathrm{~mm}$ occurred. Then about $1 \mathrm{~mm}$ difference as a reversible displacement can be observed in 1997 and 2005. After 1993 in the time when the quarry was closed, stability of the difference prevailed.

56-58: Lion Hall, NW and SE ends. The lowest level of the cave middle parts.

Diagrams crossing several times, differences reaching about $2 \mathrm{~mm}$ in 1989-1991 and 2005. However, a parallel course found generally with stabilization after 1993 when the quarry was closed.

The discussion of precise levelling results presented above comes to some general conclusions that should be respected in a future research not only in Bear Cave but even more generally when similar cave investigations is considered:

- On the couple of tectonic faults that were detected from geology in the terrain outside the cave, it was the „north” tectonic fault where the first difference in displacements was registered, showing possibly some movement reduction from the impulses coming from the quarry. One can draw a deduction that faults represented a certain barrier against Kletno I quarry blast effects. Thus, a fault function as a barrier in dynamic effects can be recognized from the results.

- Uplifts of valley bench-marks were indicated up the river, both in mica schist and marbles, with more instability in marbles which would be otherwise considered more stable. These decreases any real chance to detect more closely local internal structure planes in the massif from the results.

- Parallel development of displacements that prevails inside the cave indicates local massif dynamics with a drift to slow uplifts. On the other hand, measurement frequency does not allow detection of dynamic effects of shorter duration. This calls for an alternative geodesic measurement method.

- The end of quarry operations appeared to effect long-term dynamics found in bench-mark displacements as the drift change. However, yearly fluctuations did not disappear, which indicates that the massif is living due to tectonics and even other factors. This is a challenge for a future interdisciplinary research which would concern geology, hydrogeology, tectonics, and geophysics, but also climatology, ecology and other branches of science.

\section{ALTERNATIVE MEASUREMENTS IN THE CAVE REGARDING RELATIVE FAULT DIS- PLACEMENTS}

$3 \mathrm{D}$ relative displacements of the rock blocks inside the cave on opposite sides of the fault, on which the Palace Hall has been formed, were recorded using two crack gauges TM-71. Localization of the TM-71 is presented on Fig. 2, along with orientations of their local coordinate systems $x, y, z$ relative to the two instruments. Results of monthly observations are presented on Fig. 4 and 5. Maximum amplitude of changes during few months reached up to $0.4 \mathrm{~mm}$ having been recorded in $y$, i.e. in the coordinate that represents horizontal displacements in shear.

Accuracies of the relative displacements reach \pm $(0.01 \mathrm{~mm} \div 0.03 \mathrm{~mm})$. These are accuracies one level higher than those of the levelling measurements. The first extreme amplitude $0.4 \mathrm{~mm}$ of the horizontal displacements appeared in y and was recorded during JuneSeptember 1990 in the Water Corridor (Fig. 4). At that time the other gauge had not been installed yet. These displacements on the "y" axis, parallel to the fault direction, were confirmed to appear in connection with intensive blasting in the quarry Kletno I (Cacon et al. 1993).

Vertical displacements analysed that time from precise levelling inside the cave correlated with such crack gauge reactions. This is seen from comparison with extreme level differences found on bench-marks, e.g. points $70-71$ where absolute year's changes of up to $1 \mathrm{~mm}$ were recorded for the period 1989-1993 (Fig. 3). A similar extreme in precise levelling was recorded at the same time between the points $56-58$. It should be mentioned, of course, that levelling measurements took place in annual cycles and cannot be directly comparable in timing with monthly observations using crack gauge TM-71. The results were discussed with local officials and understood as a signal that quarry operations endanger the stability of the cave. The quarry was closed then.

There were other extremes observable on the crack gauge diagrams Figs 4 and 5. These were recorded in 1997, 1999. These two were analysed and discussed to appear coincided with Iran and Turkey (Izmit) catastrophic earthquakes producing similar reactions throughout Europe (Košták et al. 2007). The last extreme displacements, irreversible and reaching up to $0.4 \mathrm{~mm}$ in vertical coordinate $z$, was observed during 2005 (Fig. 4). This is a period of a very close earthquake (Hronov nad Metují, Czech Rep., 25.10. 2005; $\mathrm{M}_{\mathrm{L}}=3.2$; epicenter only $60 \mathrm{~km}$ from Bear Cave). 


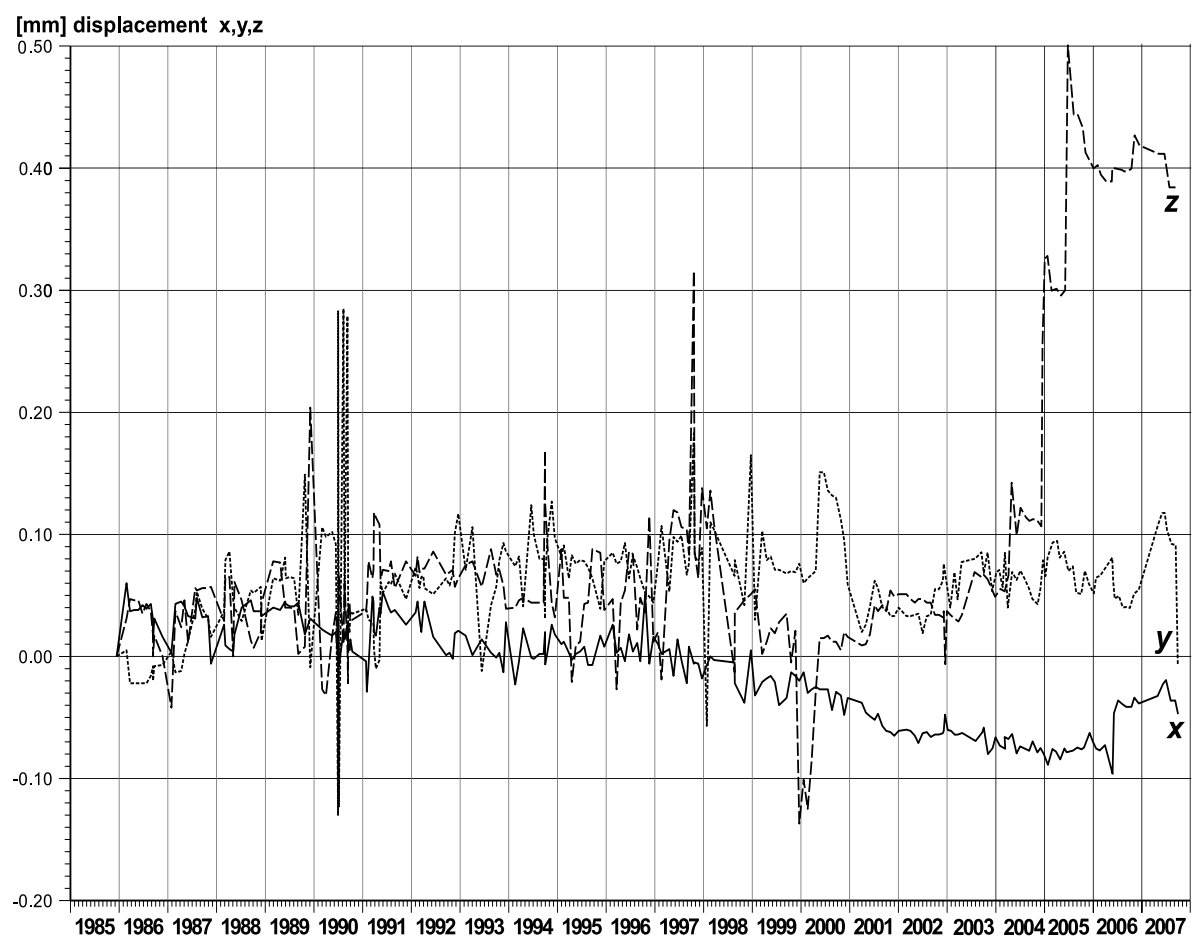

Fig. 4: Relative displacements in the Water Corridor recorded by the crack gauge TM-71.

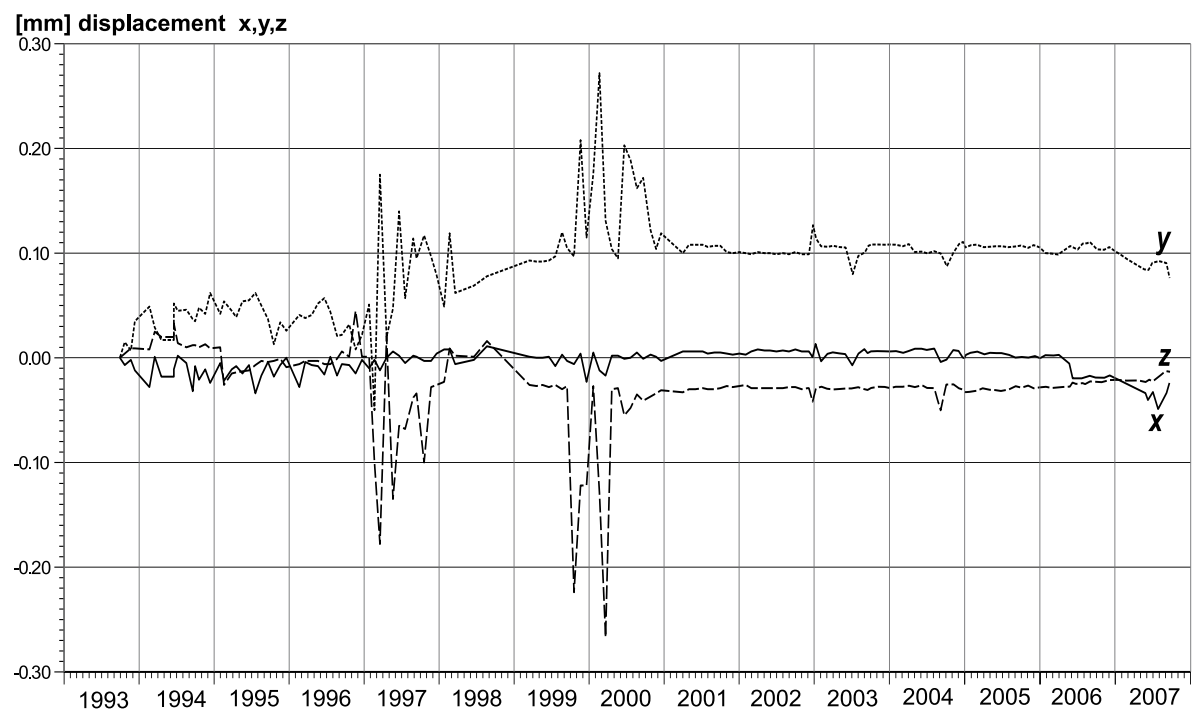

Fig. 5: Relative displacements on the Cascade Alley fault structure recorded by the crack gauge TM-71.
Such earthquake reactions were recorded by levelling measurements too, although less clearly. Some points bear signs of such movements, e.g. inside the cave difference at points 63 - 64 reads $1 \mathrm{~mm}$ just in 1997 and 2005 , and difference at points 56 - 58 reads also 1 $\mathrm{mm}$ just in 2005 .

An interesting series of higher and significant displacements appeared in the diagrams $(1-2 ; 5-6 ; 1-5$; 2 - 6; 5 - 9; 10 - 12; 14 - 23; Fig. 3) recorded by precise levelling on points outside of the cave. However, these appeared all prior to the earthquake of Hronov, being recorded in 2004. Should it be considered a precursor effect due to some deeper stress transformation in the massif occurring prior to the earthquake? Some cases of these type precursors have been reported (Košták et al. 2007) and the year 2004 is known for the catastrophic Sumatra earthquake. The fact is that in 2004 minor displacements were recorded with both the crack gauges in the cave, also (Figs. 4 and 5). 


\section{SUMMARY}

Annual precise levelling in the period of the last 22 years (1984-2006) in the surroundings and inside the unique nature object of Bear Cave, which originated in a wider tectonic fault zone of Sudeten, provided data about characteristic deformation changes in the massif. These changes, reaching up to $5 \mathrm{~mm}$ in the northern area outside the cave, where tectonic faults were detected, and between 2 and $4 \mathrm{~mm}$ inside the cave, were connected with the quarry operation of Kletno I. The quarry closed up in 1993 therefore.

The area on the surface is characterized by significant absolute vertical displacement reaching $8 \mathrm{~mm}$ and fluctuations of $10 \mathrm{~mm}$. This suggests possible effects due to partly discovered third karst level system of the Bear Cave system, or even possible existence of until now unknown voids inside the massif. Such indications could be helpful for further speleological explorations.

Bench-marks inside the cave, after the period of very intensive movements of up to $4 \mathrm{~mm}$ during the marble quarry exploitation, changed then their behaviour producing slight but systematic uplifts. Fault observations using TM-71 are not fully comparable with results of the levelling because of different sensitivity range in which the two procedures were operating and because of different observation frequency. Amplitudes recorded with TM-71 in horizontal and vertical displacements reaching up to $0.4 \mathrm{~mm}$ occur to be in the range of mean errors received during repeated levelling measurements. Nevertheless, the two measurement procedures were complementary and both confirmed the occurrence of the unacceptable effect of quarry operations.

Periods of increased amplitudes of rather fast development recorded by TM-71 were reported coincided with some earthquakes, which has been reported even elsewhere (Šebela et al. 2005). Iran and Turkey (Izmit) catastrophic earthquakes produced similar reactions throughout Europe (Košták et al. 2007), and the last extreme displacement in the Bear Cave, irreversible and reaching $0.4 \mathrm{~mm}$ in vertical coordinate $\mathrm{z}$, was observed in 2005 (Fig. 4), when an earthquake of a very close epicenter occurred (Hronov nad Metují, Czech Rep., 25.10. 2005; $\mathrm{ML}=3.2$; epicenter only $60 \mathrm{~km}$ from Bear Cave.)

Results like that call for further investigations that could improve our knowledge about the Earth, massif behaviour, living cave rock, while making most of the advantage of cave environment with relatively stable external conditions.

Research into cave deformations comprising measurements of this kind - either geodetic or extensiometric, is technically difficult for the demand of high precision procedures and prolonged time of observation. Nevertheless, it is obvious that such a research should be undertaken and is going to be continued even in Bear Cave.

\section{REFERENCES}

Cacoń, S., Kaczałek, M. \& Mąkolski, K., 1989: Badania deformacji masywu Jaskini.- In: "Jaskinia Niedźwiedzia w Kletnie - badania i udostępnianie", red.: A. Jahn, S. Kozłowski, T. Wisznowska, PWN, Oddział we Wrocławiu, 1989, pp. 157-167 (in Polish).

Cacoń, S., Košták, B. \& Mąkolski, K., 1993: Monitoring and interpretation of ground deformation of a cave.- Seventh International FIG Symposium on Deformation Measurements, Canada, Banff, 1993, pp. 440-449.

Cacoń, S., Ciężkowski, W., Don, J., Hutnik, R. \& Rippel, J., 1993: Ocena wpływu działalności kamieniołomu marmuru w Kletnie na Jaskinię Niedźwiedzią.Przegl. Geol. 1993 R. 41 nr 10 pp. 706-712. (in Polish).
Cacoń, S., Košták, B., Mąkolski, K., 1996: Deformacje górotworu Jaskini Niedźwiedziej wskutek antropopresji.- In: „Masyw Śnieżnika”, red.: Jahn A., Kozłowski S., Pulina M., Wyd. Polskiej Agencji Ekologicznej, Warszawa 1996, pp. 71-83. (in Polish).

Ciężkowski, W., 2006: Jaskinia Niedźwiedzia w liczbach.In: „Jaskinia Niedźwiedzia w Kletnie - 40 lat eksploatacji, badań, ochrony i turystyki", red. Ciężkowski W., Wyd. Maria, Nowa Ruda, 2006, pp. 33-34.

Czaja, J. \& Latoś S., 1996: Estimation of linear deformation models.- Proc. of $8^{\text {th }}$ FIG Int. Symp. On Deformation Measurements, 25-28 June 1996, Hong Kong 1996.

Don, J. \& Opletal, M., 1996: Budowa i ewolucja geologiczna Masywu Śnieżnika.- In: „Masyw Śnieżnika”, red.: A. Jahn, S. Kozłowski, M. Pulina, Wyd. Polskiej Agencji Ekologicznej, Warszawa 1996, pp. 13-26. 
Hellwig, Z., 1978: Elementy rachunku prawdopodobieństwa i statystyki matematycznej.- $P W N$, Warszawa 1978.

Košták, B., Cacoń, S., Dobrev, N. D., Avramova-Tačeva, E., Fecker, E., Kopecký, J., Petro, L., Schweitzer, R. \& Nikonov A. A., 2007: Observations of Tectonic Microdisplacements in Europe in Relation to the Iran 1997 and Turkey 1999 Earthquakes.- Izvestiya, Physics of the Solid Earth, 2007, vol. 43, no. 6, pp 503-516, Pleiades Publishing 2007.
Milev, G. \& Papo, H., 1998: Classification of Methods and Models for Deformation, Analysis and Interpretation of Deformations.- Proc. XXI FIG Int. Congress On Developing the Profession in a Developing World, Comm. 6, Brighton 1998.

Šebela, S., Gosar, A., Košták, B. \& Stemberk, J., 2005: Active tectonic structures in the $\mathrm{W}$ part of Slovenia - Setting of micro-deformation monitoring net. - Acta Geodyn. Geomat. 2, 1, (137), pp. 45-57, ISSN: 1214-9705. 